\title{
Screening of Anthraquinones and Assessment of Antimicrobial Activities of Ethanol Extracts of AdansoniadigitataL., Sudan
}

\author{
M. H. A. Suleiman ${ }^{1,2, *}$, Y. A. I. Ahmed ${ }^{2}$, A. A. Osman ${ }^{3}$ \\ ${ }^{1}$ Department of Chemistry, Faculty of Science, King Khalid University, Abha, Saudi Arabia \\ ${ }^{2}$ Department of Chemistry, Faculty of Science, University of Kordofan, El Obeid, Sudan \\ ${ }^{3}$ Department of Chemistry, College of Science and Home economic, Bisha University, Saudi Arabia
}

\begin{abstract}
The aim of the study was to investigate anthraquinones and to determine the antimicrobial activity of different extracts of Adansoniadigitata L., a plant used by Sudanese communities to treat various ailments such as diarrhea and microbial infections. The anthraquinones were screened qualitatively. The presences of anthraquinones were detected in ethanol extracts along with acetone and ethyl acetate fractions of both fruits fibers and fruits cover of $A$. digitata. The fruits fibers and fruits cover extracts were screened for antimicrobial activityagainst Gram-positive (Bacillus subtilis and Staphylococcus aureus), and Gram-negative bacterial strains (Escherichia coli, Pseudomonas aeruginosa, Proteus vulgaris and Klebsiella pneumoniae), and two fungi (Candida albicans and Aspergillus niger)using agar well diffusion method. Results showed that the fruits covers extract was exerted highest activity on bacterial agents tested compared to fruits fibers extract, and fruits fibers extract was the most effective against fungi (A. niger), while both extracts were not active against $C$. albicans. Fruits cover extract at concentration of $100 \mu \mathrm{g} / \mathrm{ml}$ showed $25 \mathrm{~mm}$ diameter zone of inhibition against P.vulgaris. This was followed by 23, 22 and $21 \mathrm{~mm}$ zone of inhibition against B. subtilis, K. pneumoniae and $S$. aureus. TLC analysis revealed the presence of two anthraquinones compounds in the acetone extract of the fruits cover.
\end{abstract}

Keywords: Adansoniadigitata, Antibacterial, Antifungal, Anthraquinones, Sudan

\section{Introduction}

Medicinal plants have formed the basis of health care throughout the world since the earliest days of humanity and are still widely used and have considerable importance in International trade [1]. The medicinal value of plants lies in the presence of chemical substancesfound as secondary plant metabolites that definitely produce a physiological action on the human body. The interest in using phytochemicals for the treatment of microbial infections increased in the late 1990's with the increased inefficacy of conventional antibiotics, due in part to their often excessive and in appropriateuse in mammalian infections [2]. The most important of these bioactive compounds in plantsare alkaloids, anthraquinones, flavonoids, saponins, tannins and other chemical compounds [3],[4].

The use of medicinal plants as traditional medicines is wellknown in rural areas of many developing countries [5].Most of the Sudanese people in rural areas rely on traditional medicine for the treatment of many infectious diseases [6].

Thus, the aim of this study was to evaluate the activity of the fruits covers and fruits fibersextracts as well as to detect the presence of anthraquinonesin Adasoniadigitata L. a plant traditionally used for medicinal purposes in Sudan.

\section{Review of Literature}

\subsection{Adansoniadigitata L.}

A. digitataL.(Malvaceae) (Fig. 1), the African baobab, is a tree widespread throughout the hot regionsof tropical Africa [7].It is a deciduous, massive and majestic tree up to $25 \mathrm{~m}$ high, which may live for hundreds of years [8]. InSudan, the baobab tree is called Tebaldi, and it is most frequently found on sandy soils and by seasonal streams in short grass savannas. It forms belts throughout Central Sudan,Kordofan, Darfur and Blue Nileregions [9].

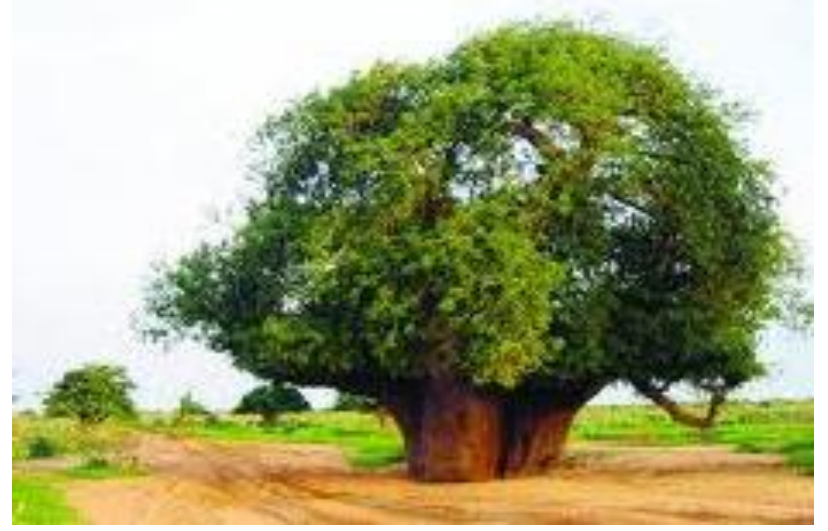

Figure 1: A. digitata(baobab) tree

\subsubsection{Medicinal and folkloric uses of $\boldsymbol{A}$. digitata}

Baobab has a long history of traditional uses as a treatment against fevers, dysentery, and bleeding wounds, and it has a long history of nutritional and medical use in Africa [10].Baobab fruits and leaves are used in folk medicine by communities of North Kordofan, Sudan against dysentery, 


\section{International Journal of Science and Research (IJSR) \\ ISSN (Online): 2319-7064}

Index Copernicus Value (2013): 6.14 | Impact Factor (2014): 5.611

stomach pains, diarrhea, fever and the infusion of the fruits covers for kidney stones [11].The aqueous extract of baobab fruit pulp exhibited significant hepatoprotective activity [12].Ramadan et al., 1994 reported that the analgesic and antipyretic activitiesof baobab may be due to the presence of sterols, saponins and triterpenes[13].The fruit can be used for the treatment of fever, diarrhea, dysentery, hemoptysis and small pox [14].

Previousphytochemical studies of various parts of baobab (fruit pulp, bark, seed oil, leaves, roots) have resultedintheidentification and isolationofvarious phytochemicals includingterpenoids, flavonoids, sterols, vitamins, amino acids, carbohydrates and lipids[15].

\subsubsection{Antimicrobial activity of $\boldsymbol{A}$.digitata}

Masola et al. (2009) found that the aqueous and ethanolic extracts of the root and stem bark of $A$. digitata was active against Gram-positive bacteria, Gram-negative bacteria and yeast. The results indicated that these extracts inhibited the growth of the microorganisms tested with MIC values ranging from 1.5 to $6 \mathrm{mg} / \mathrm{ml}$. The antibacterial activity of the plant could be attributed to the presence of tannins, terpenoids and saponins in the stem and root bark[16].This result was in agree with the study carried out byAnaniet al.(2000) andYagoub (2008) who investigated the antibacterial activity of a solvent extract of $A$. digitata against E. coli isolated from urine and water[17], [18]. The results clearly indicated that the solvent extract inhibited bacterial growth with the inhibition zone ranging from 20 to $30 \mathrm{~mm}$ depending on the concentration at which the sample was tested [18].

\subsection{Anthraquinones}

In plants, anthraquinones are found in a wide range of species, especially in the plant families Rubiaceae, Polygonaceae, Rhamnaceae,Fabaceae, and Xanthorrhoeaceae[19]- [22]. Anthraquinone compounds and plants that contain them are widely used as mild laxatives [23], [24]. Besides their purgative properties, anthraquinones possess antibacterial, antiviral [25], antifungal [26], antioxidant [27] and anticancer [28] properties.

\section{Materials and Methods}

All chemicals, solvents and reagents used were of analytical grade. Most of the chemicals used were supplied by Fisher Scientific (Springfield, NJ), British Drug Houses (England) and Sigma ${ }^{\circledR}$ (Germany), and were of the purest grade available.

\subsection{Plant Materials}

The plant materials, fruits fibers and fruits covers (Fig. 2) of A. digitata were collected from the area around El Obeid city the capital of Northern Kordofan state, Sudan in December 2013 and authenticated by the researchers at National Research Center, Khartoum, Sudan. Plant materials were dried under shade and pulverized into powdered forms. They were then stored in air tight bottles and were used for all the extraction process.
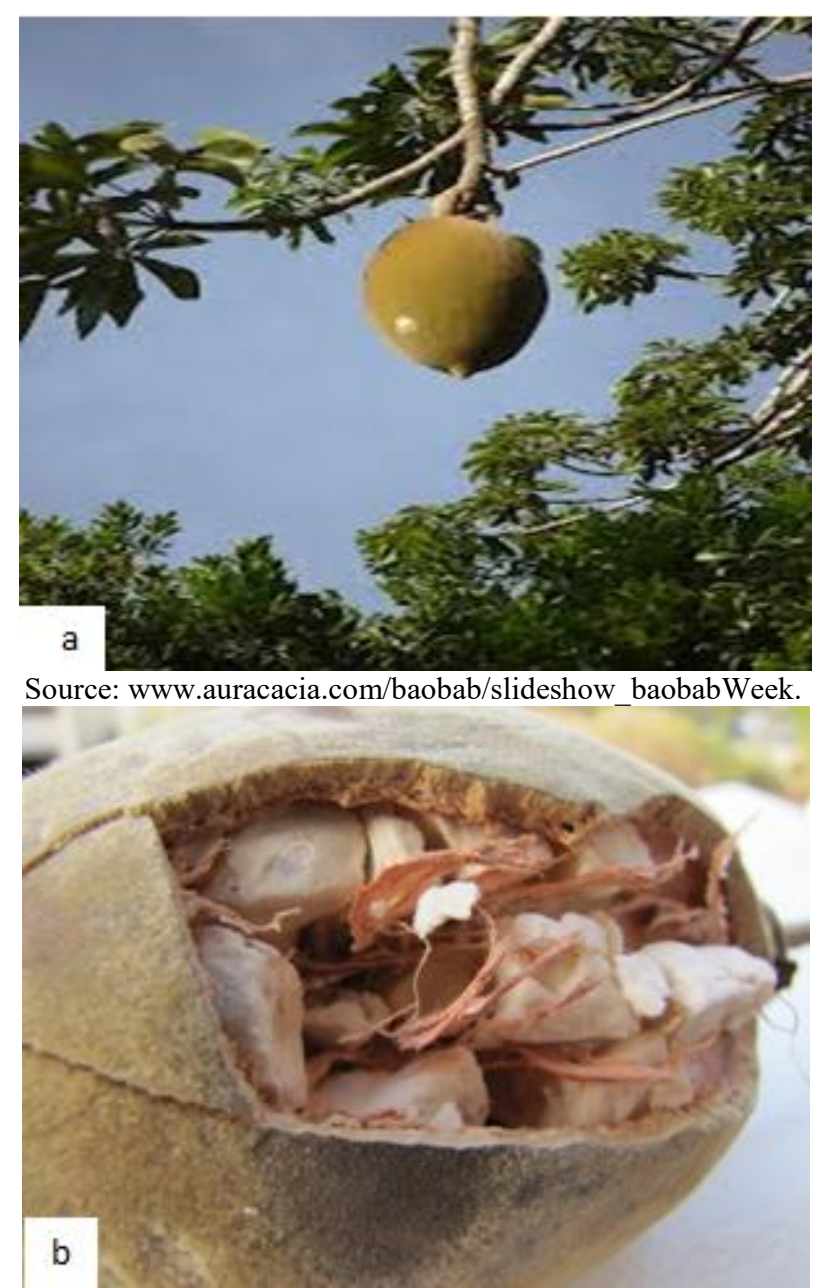

Figure 2: (a) A. digitata (baobab) fruit; (b) fruit cover and fibers

\subsection{Extraction}

\subsubsection{Maceration extraction}

Hundred gramsof powdered plant material was extracted three times with ethanol during three days at room temperature. The extract was filtered and the solvent was removed under reduced pressure, then air dried. Same process was done for making extracts of both fruits fibers and fruits cover.

\subsubsection{Soxhlet extraction}

Dried and powdered fruits fibers $(20 \mathrm{~g})$ of A. digitata was successively extracted in a Soxhlet apparatus, with hexane followed by ethyl acetate, acetone, and finally methanol with $200 \mathrm{ml}$ of each solvent for 6 hours. The extracts were filtered before drying using Whatman filter paper No. 2 on a Büchner funnel and the solvent removed by vacuum distillation in a Büchi rotary evaporator (BÜCHI Rota-vapor R-200) at 60 ${ }^{\circ} \mathrm{C}$, care being taken to decrease the temperature to $40^{\circ} \mathrm{C}$ for the final drying. For quantitative determination, the extracts were placed in pre-weighed flasks before drying. The dried extracts was kept in a refrigerator till used. This process was repeated for extraction of fruits cover of $A$. digitata.

\subsection{Test for anthraquinones}

The extract $(0.5 \mathrm{~g})$ was shakenwith an aliquot of $10 \mathrm{~mL}$ of benzene. The mixture was filteredand an aliquot $5 \mathrm{~mL}$ of 


\section{International Journal of Science and Research (IJSR) \\ ISSN (Online): 2319-7064 \\ Index Copernicus Value (2013): 6.14 | Impact Factor (2014): 5.611}

$10 \%$ ammonia solution wasadded to the filtrate and the final mixture was shaken and the two layers allowed separating. The presence of anthraquinones was indicated by pink or red coloration of the lower alkaline layer [29], [3].

\subsection{Antimicrobial activities}

\subsubsection{Microorganisms used}

The bacteria used were Escherichia coli (ATCC 25922), Pseudomonas aeruginosa (ATCC 27853), Staphylococcus aureus (ATCC 25923), Bacillus subtilis(NCTC 8236), Proteus vulgaris (ATCC 6380) and Klebsiella pneumoniae (ATCC 53657). The fungi used were Candida albicans(ATCC 7596), and Aspergillus niger(ATCC 9763).

\subsubsection{Antimicrobial activity test}

The agar-well diffusion method as described by Irobi et al.,(1996)[30], with modifications was adopted to assess the antibacterial and antifungal activities of the crude extracts. The bacterial cultures were inoculated onto nutrient agar medium. A sterile cork borer was used to make a well (6 $\mathrm{mm}$ in diameter) on the Nutrient Agar plates. $100 \mu \mathrm{l}$ of each extracts at concentrations of $100 \mu \mathrm{g} / \mathrm{ml}$, were applied separately in each of the wells in the culture plates previously seeded with the test organisms. Plates were incubated at 37 ${ }^{\circ} \mathrm{C}$ for $24 \mathrm{~h}$. Controls were set up in parallel using the solvents that were used to reconstitute the extract. Antibacterial activities were evaluated by measuring the zone of inhibition around each well (excluding the diameter of the well). For each extract, three replicate trials were conducted against each organism.

The same method as for bacteria was adopted for antifungal activity. Instead of nutrient agar, sabouraud dextrose agar was used. The inoculated medium was incubated at $25^{\circ} \mathrm{C}$ for one day for C.albicansand two days for A. niger.

Extracts causing a zone of inhibition of $>20 \mathrm{~mm}$ were considered highly active and thosehaving a zone of inhibition of $<20 \mathrm{~mm}$ were considered moderatelyactive.

\subsection{Thin layer chromatography}

Acetone and ethyl acetate extracts obtained by Soxhlet extraction for both fruits cover and fruits fibers were subjected to thin layer chromatography (TLC) for the separation of polar and non-polar compounds. The solvent system used as mobile phase was toluene: ethyl acetate: formic acid $(4: 5: 1, v / v)$. The plates were sprayed with natural product reagent and visualized under ultraviolet light $(365$ $\mathrm{nm}$ ). Identification was done on the basis of color and $\mathrm{Rf}$ value under UV light at $365 \mathrm{~nm}$.

\section{Results and Discussion}

\subsection{Test for anthraquinones}

The ethanol extracts obtained by maceration method along with hexane, ethyl acetate, acetone and methanol extracts obtained from Soxhletextraction for both fruits fibers and fruits cover were tested for the presence of anthraquinones. In the screening process the two ethanol extracts along with ethyl acetate and acetone extracts (of both fruits fibers and fruits cover) were gave positive results (pink to red coloration),while hexane and methanol extracts gave negative results. For the best of our knowledge this is the first study indicating the presence of anthraquinones in $A$. digitata. The presence of anthraquinones in the fruits fibers and fruits cover extracts may be responsible for the antimicrobial activity of the plantextracts.

\subsection{Assessment of antimicrobial activities}

Preliminary screening of the antimicrobial activity in vitro offruits fibers and fruits cover ethanol extracts was studied against eightpathogen microorganisms. The results showed variation in the antimicrobial properties of plant extracts (Table 1 and Fig. 3-10).The fruits coverextract exerted highest activity on bacterial agents tested compared to fruits fibers extract. The fruits fibers extract at the concentration of $100 \mu \mathrm{g} / \mathrm{ml}$ showed $25 \mathrm{~mm}$ diameter zone of inhibition against P.vulgaris. This was followed by 23, 22 and $21 \mathrm{~mm}$ zone of inhibition against B.subtilis, K.pneumoniaeand $S$. aureus. The results showed that the fruits fibers extract was more effective than fruits cover extract against fungi ( $A$. niger), while both extracts were not active against $C$. albicans. However, the fact thatthe fruits cover extract was active against both gram-negative and gram-positive bacteria may provide scientific bases for the local usage of this plant part in the treatment of various ailments, especially dysentery and diarrhea.

Table 1: Antimicrobial activity of extracts

\begin{tabular}{|c|c|c|}
\hline \multirow[t]{3}{*}{ Microorganisms } & \multicolumn{2}{|c|}{ Inhibition zone (mm) } \\
\hline & \multicolumn{2}{|c|}{ Ethanol extracts } \\
\hline & Fruits cover & Fruits fibers \\
\hline E.coli & 20 & 19 \\
\hline P.aeruginosa & 20 & 18 \\
\hline K.pneumoniae & 22 & 19 \\
\hline P.vulgaris & 25 & - \\
\hline B.subtilis & 23 & - \\
\hline S. aureus & 21 & 18 \\
\hline C.albicans. & - & - \\
\hline A. niger & 20 & 22 \\
\hline
\end{tabular}

* $>20 \mathrm{~mm}=$ highly active; $15-20 \mathrm{~mm}=$ moderately active; $=$ Negative

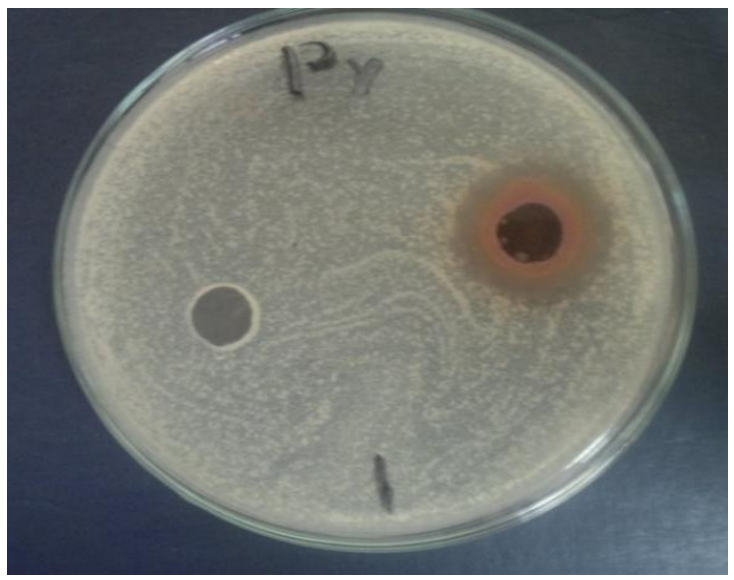

Figure 3: Inhibition zone ofthe ethanol extracts offruits cover against $P$.vulgaris 


\section{International Journal of Science and Research (IJSR)}

ISSN (Online): 2319-7064

Index Copernicus Value (2013): 6.14 | Impact Factor (2014): 5.611

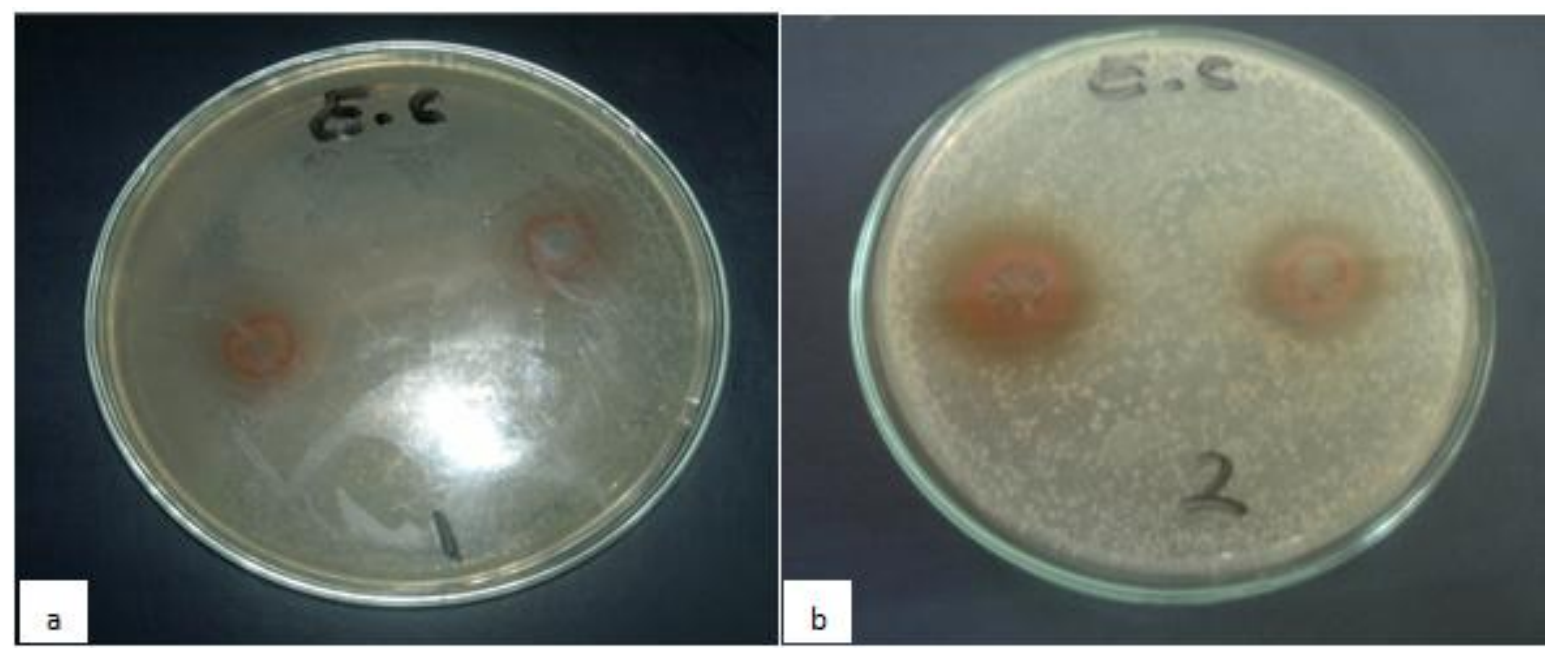

Figure 4: Inhibition zone ofthe ethanol extracts (a: fruits fibers; b: fruits cover) against $E$. coli

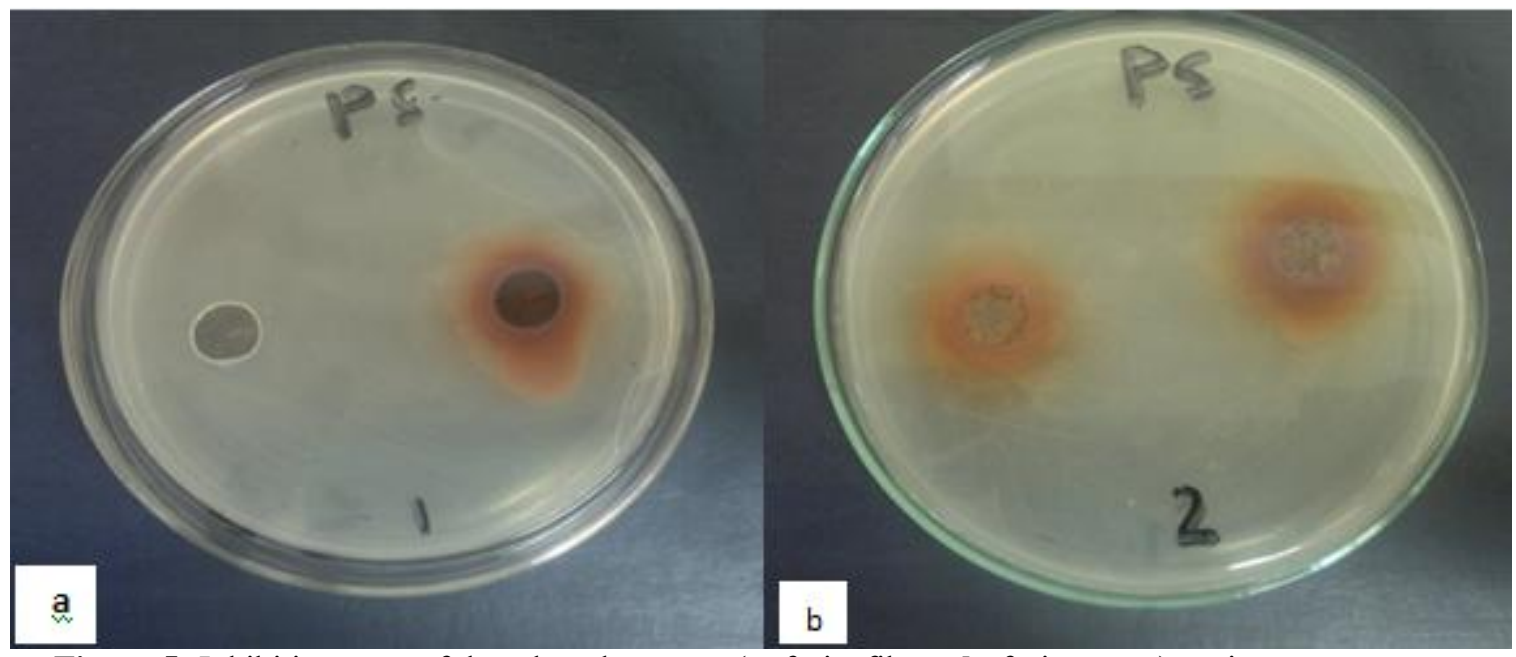

Figure 5: Inhibition zone of the ethanol extracts (a: fruits fibers; $\mathbf{b}$ : fruits cover) againstP.aeruginosa
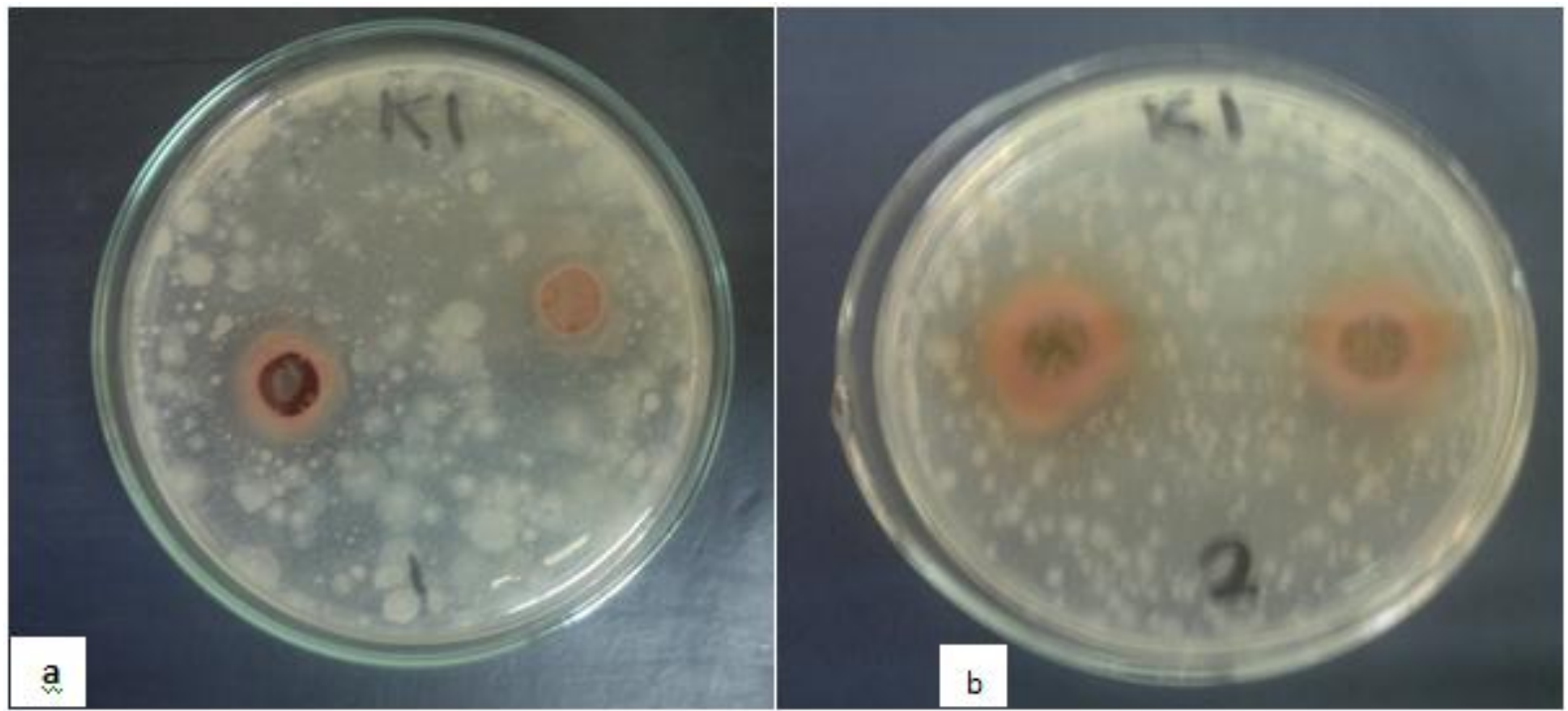

Figure 6: Inhibition zone ofthe ethanol extracts (a: fruits fibers; b: fruits cover) against K. pneumoniae

Volume 5 Issue 1, January 2016 www.ijsr.net 


\section{International Journal of Science and Research (IJSR)}

ISSN (Online): 2319-7064

Index Copernicus Value (2013): 6.14 | Impact Factor (2014): 5.611

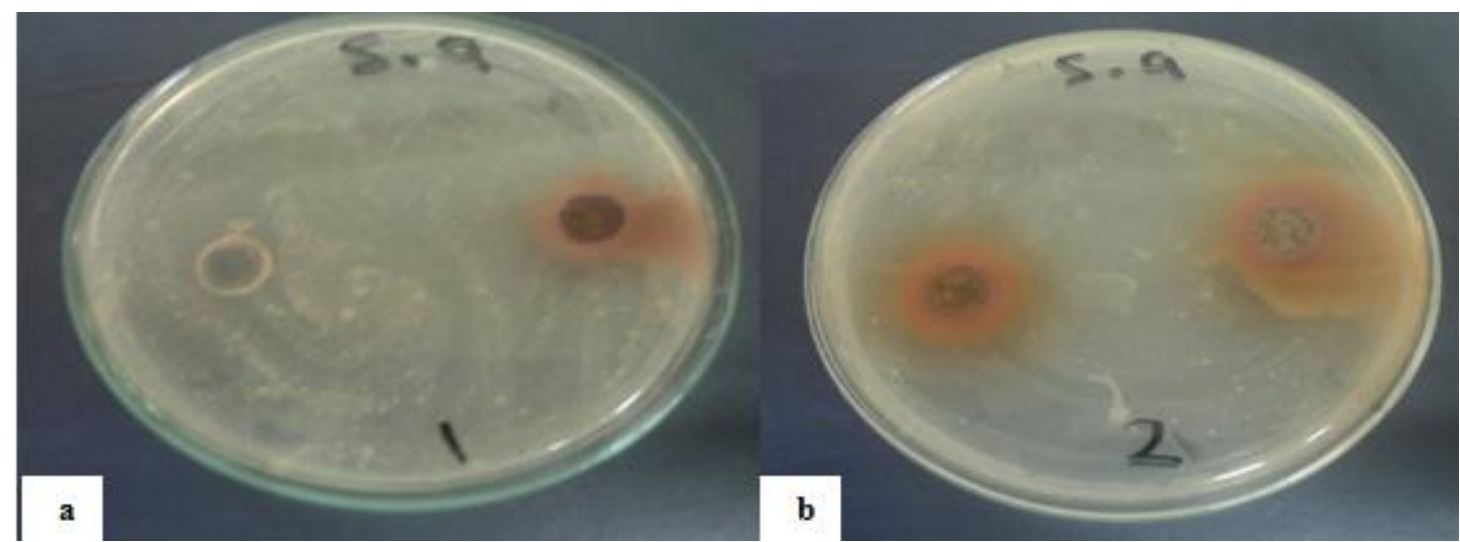

Figure 7: Inhibition zone ofthe ethanol extracts (a: fruits fibers; b: fruits cover) against $S$. aureus

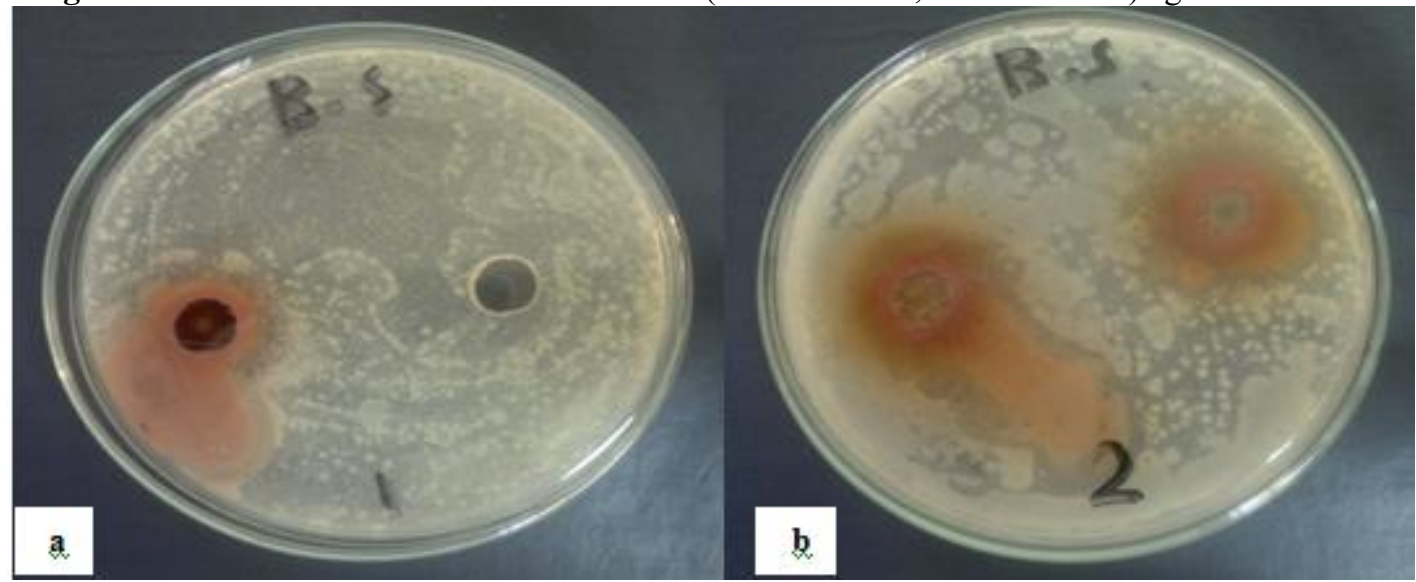

Figure 8: Inhibition zone ofthe ethanol extracts (a: fruits fibers; b: fruits cover) against B. subtilis

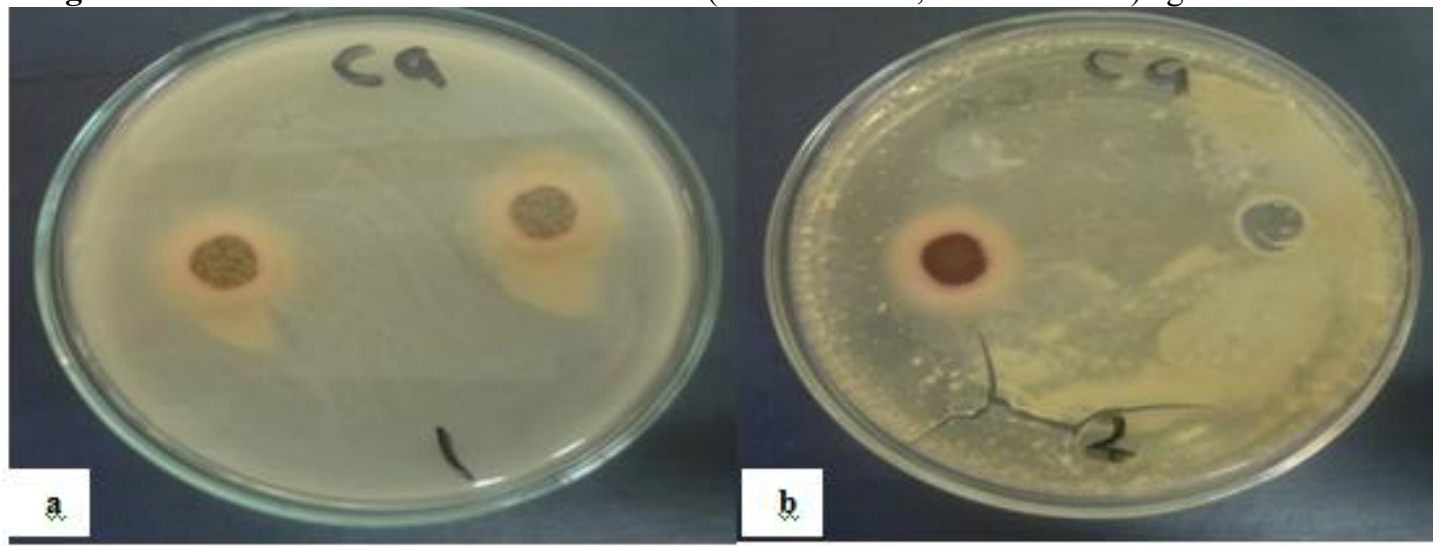

Figure 9: Inhibition zone of the ethanol extracts (a: fruits fibers; b: fruits cover) against C.albicans

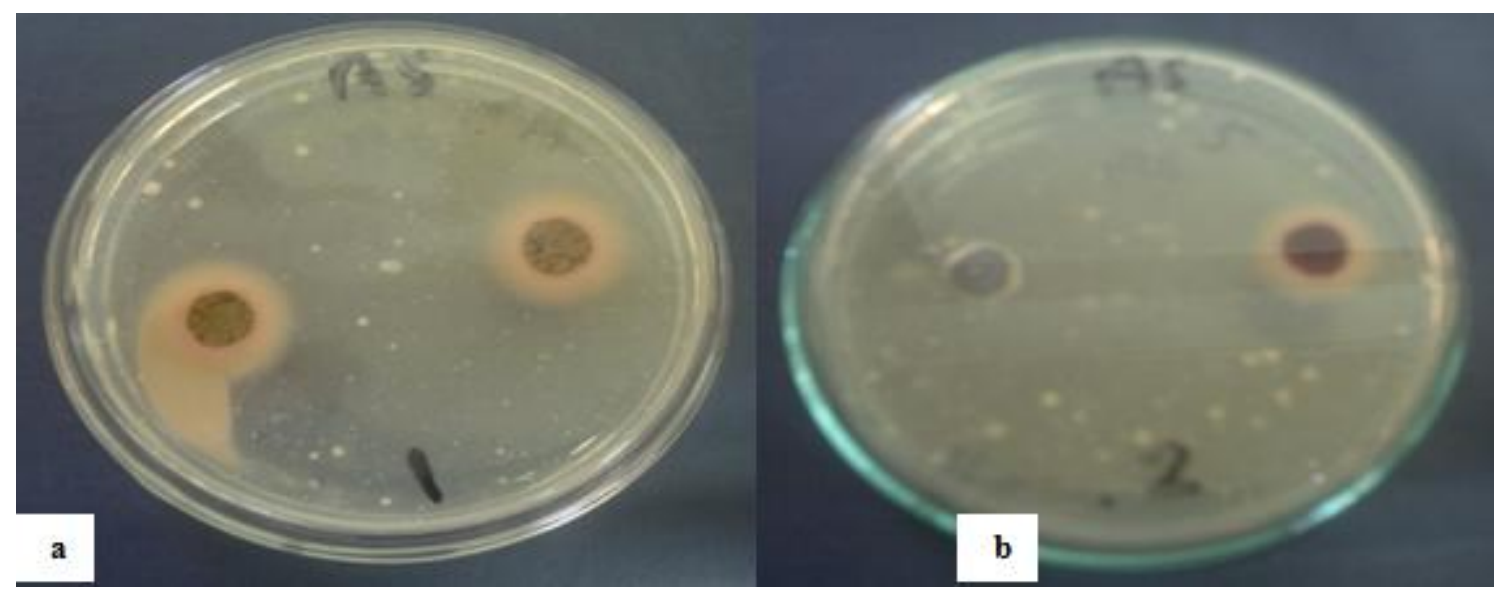

Figure 10: Inhibition zone of the ethanol extracts (a: fruits fibers; $\mathbf{b}$ : fruits cover) against A.niger

Volume 5 Issue 1, January 2016 www.ijsr.net 


\section{International Journal of Science and Research (IJSR) \\ ISSN (Online): 2319-7064 \\ Index Copernicus Value (2013): 6.14 | Impact Factor (2014): 5.611}

4.3 TLC analysis of acetone and ethyl acetate extracts of fruits cover

Acetone and ethyl acetate extracts obtained by Soxhlet extraction for both fruits cover and fruits fibers were subjected to thin layer chromatography performed on a precoatedaluminium plate of silica gel $60 \mathrm{~F}_{254}(10 \times 20 \mathrm{~cm})$ using toluene: ethyl acetate: formic acid (4:5:1) as the mobile phase. After removing the plate from the chamber, the plate was dried using an air dryer and spray with natural product reagent then visualized under UV 365. Antharaquinones show yellow spots [31].The Rf values and colors of the separated compounds are shown in Table (2). UV active compounds, component-1 (retardationfactor or $\mathrm{Rf}$ value $=$ 0.35 and colorationBrown/Yellow, the compoundwould be anthraquinone), and component-2 $(\mathrm{Rf}=0.55 \mathrm{and}$ colorationYellow/ Yellow, the compound would be anthraquinone) were observed inthe acetone extract of fruits cover.

Table 2: TLC of acetone extract of the fruits cover

\begin{tabular}{|c|c|c|c|}
\hline Components & Rf value & $\begin{array}{c}\text { Color with } \\
\text { spray reagent }\end{array}$ & $\begin{array}{c}\text { Color under UV } \\
365 \mathrm{~nm}\end{array}$ \\
\hline 1 & 0.35 & Brown & Yellow \\
\hline 2 & 0.55 & Yellow & Yellow \\
\hline
\end{tabular}

- Mobile phase: toluene: ethyl acetate: formic acid (4:5:1)

- Stationary phase: silica gel $60 \mathrm{~F}_{254}$

- Spray reagent: natural product reagent (NPR)

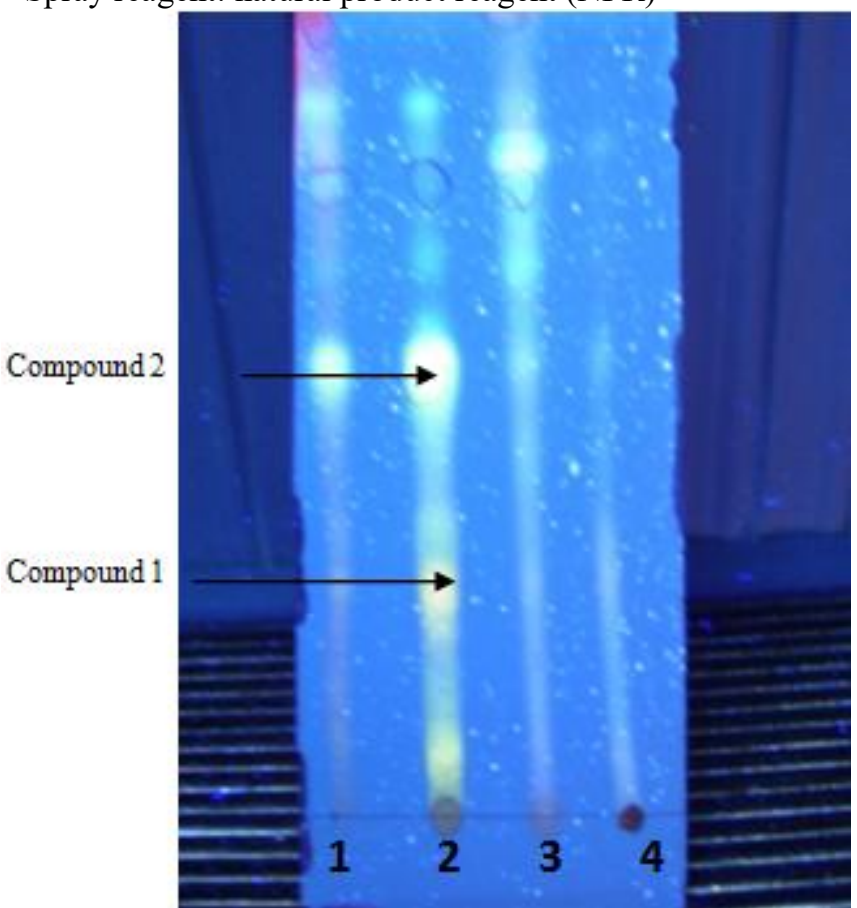

Figure 11: TLC of A.digitataextracts sprayed with NPR and detected under UV365 nm (1 = ethyl acetate extract (fruits cover); $\mathbf{2}$ = acetone extract (fruits cover); $\mathbf{3}=$ ethyl acetate extract (fruits fibers); $\mathbf{4}=$ acetone extract (fruits fibers)

\section{Conclusion}

In this study the ethanol extracts of fruits cover and fruits fibers of $A$. digitata were screened for antimicrobial activity using agar-well diffusion method. The extracts were also screened for the presence of anthraquinones. The fruits covers extract exerted highest activity on bacterial agents tested compared to fruits fibers extract and fruits fibers extract was the most effective against fungi (A. niger), while both extracts were not active against $C$. albicans. The fruits cover extract showed $25 \mathrm{~mm}$ diameter zone of inhibition against $P$. vulgaris. Phytochemical screening of anthraquinones showed positive results for both extracts of $A$. digitata. TLC analysis revealed the presence of two anthraquinones in acetone fraction of the fruits cover. The antimicrobial activity may attribute to anthraquinones. However, the activity of $A$. digitata different extracts against both gram-negative and gram-positive bacteria strains tested may provide scientific bases for the local usage of the plant in the treatment of various ailments, especially dysentery and diarrhea.

\section{Acknowledgements}

The authors thank the researchers at National Research Center, Khartoum, Sudan.

\section{References}

[1] Ahmad, F. Agil, and M. Owais, Modern Phytomedicine: Turning Medicinal Plants into Drugs, West-Sussex England, John Wiley and Sons, pp. 2-24, 2006.

[2] M.M. Cowan, Plant Products as Antimicrobial Agents, Clin. Microbiol. Rev., 12 (4), pp. 564-582, 1999.

[3] J.B. Harborne, Phytochemical Methods: A Guide to Modern Techniques of Plant Analysis, 3rd edition, Springer, UK, 1998.

[4] H.O. Edeoga, D.E. Okwu, and B.O. Mbaebie, Phytochemical constituents of some Nigerian medicinal plants, African Journal of Biotechnology, 4, pp. 685$688,2005$.

[5] M.P. Gupta, P.N. Solis, A.I. Calderon, F. GuionneauSinclair, M. Correa, C. Galdames, Medical ethnobotany of the Teribes of Bocas del Toro, Panama, J. Ethnopharmacol., 96, pp. 389-401, 2005.

[6] I.E. Mohamed, E.E. El nur, and M.E. Abdurrahman, The antibacterial, antiviral activities and phytochemical screening of some Sudanese medicinal plants. EurAsia J BioSci., 4 (2), pp. 8-16, 2010.

[7] FAO. Traditional food plants, Food and Agriculture Organization of the United Nations, Rome, 24, pp. 6367, 1988.

[8] J. Gebauer, K. El-Siddig, and G. Ebert, Baobab (AdansoniadigitataL.): a Review on a Multipurpose Tree with Promising Future in the Sudan, Gartenbauwissenschaft, 67 (4), pp. 155-160, 2002.

[9] H.M. El Amin, Trees and shrubs of the Sudan, Ithaca press, Exeter, London, 1990.

[10] A.G. Diop, M. Sakho, M. Dornier, M. Cissé, and M. Reynes, Le baobab africain (AdansoniadigitataL.): principalescaractéristiquesetutilisations, Fruits, 61, pp. 55-69, 2005

[11] M.H.A. Suleiman, “An ethnobotanical survey of medicinal plants used by communities of Northern Kordofan region, Sudan,’J. Ethnopharmacol., 176, pp. 232-242, 2015. 


\section{International Journal of Science and Research (IJSR) \\ ISSN (Online): 2319-7064 \\ Index Copernicus Value (2013): 6.14 | Impact Factor (2014): 5.611}

[12] Al-Qarawi, M.A. Al-Damegh, and S.A. El-Mougy, Hepatoprotective Influence of AdansoniadigitataPulp, J. Herbs Spices Med. Plants, 10, pp. 1-6, 2003.

[13] Ramadan, F.M. Harraz, and S.A. El-Mougy, Antiinfiammatory, analgesic and antipyretic and effects of the fruit pulp of Adansoniadigitata, Fitoterapia, 65 (5), pp. 418-422, 1994.

[14] J. Gruenwald and M. Galizia, "Market Brief in the European Union for selected natural ingredients derived from native species -Adansoniadigitata L. (Baobab), " In The United Nations Conference on Trade and Development (UNCTAD), pp. 1-35,2005.

[15] G.P.P. Kamatou, I. Vermaak, and A.M. Viljoen,"updated review of Adansoniadigitata: A commercially important African tree,"South African Journal of Botany, 77, pp. 908-919, 2011.

[16] S.N. Masola, R.D. Mosha, and P.N. Wambura, Assessment of antimicrobial activity of crude extracts of stem and root barks from Adansoniadigitata (Bombacaceae) (African Baobab), African Journal of Biotechnology 8, 5076-5083, 2009.

[17] K. Anani, J.B. Hudson, C. de Souzal, K. Akpaganal, G.H.N. Tower, J.T. Amason, and M. Gbeassor, Investigation of medicinal plants of Togo for antiviral and antimicrobial activities,Pharmaceutical Biology, 38 , pp. $40-45,2000$.

[18] S. Yagoub, Antimicrobial activity of Tamarindusindica and Adansoniadigitata extracts against E. coli isolated from urine and water specimens, Research Journal of Microbiology 3, pp. 193-197, 2008.

[19] R. Singh, and S. M. Chauhan, 9,10-Anthraquinones and other biologically active compounds from the genus Rubia, Chemistry \& Biodiversity, 1 (9), pp. 1241-1264, 2004.

[20] Mathey, P. Spiteller, and W. Steglich, Draculone, a new anthraquinone pigment from the tropical lichen Melanothecacruenta,ZeitschriftfurNaturforschung $\mathrm{C}$ : Journal of Biosciences, 57 (7-8), pp. 565-567, 2002.

[21] V. Ivanova, R. Schlegel, and U. Grafe, 2-Methoxy4,5,7- trihydroxy-anthraquinone, a new lichen metabolite produced by Xanthoriaparietina, Die Pharmazie, 55 (10), pp. 785-786, 2000.

[22] S. Kanokmedhakul, K. Kanokmedhakul, N. Phonkerd, K. Soytong, P. Kongsaeree, and A. Suksamrarn, "Antimycobacterialanthraquinone-chromanone compound and diketopiperazine alkaloid from the fungus ChaetomiumglobosumKMITLN0802," Planta Medica, 68 (9), pp. 834-836, 2002.

[23] Sakulpanich, and W. Gritsanapan, Determination of Anthraquinone Glycoside Content in Cassia fistula Leaf Extracts for Alternative Source of Laxative Drug, International Journal of Biomedical and Pharmaceutical Sciences, 3 (1), pp. 42-45, 2009.

[24] K. B. G. Torsell, Natural Product Chemistry: A Mechanistic, Biosynthetic and Ecological Approach, 2nd edition, Swedish Pharmaceutical Press, Stockholm, Sweden, 1997.

[25] B.O. Ifesan, C. Hamtasin, W. Mahabusarakam, S.P. Voravuthikunchai, Assessment of antistaphylococcal activity of partially purified fractions and pure compounds from EleutherineAmericana, Journal of Food Protection, 72, pp. 354-359, 2009.
[26] S.K. Agarwal, S.S. Singh, S.Verma, S. Kumar, Antifungal activity of anthraquinone derivatives from Rheum emodi, J. Ethnopharmacol. 72, pp. 43-46, 2000.

[27] R.B. Ammara, W. Bhouri, M.B. Sghaier, J. Boubaker, I. Skandrani, A. Neffati, Antioxidant and free radicalscavenging properties of three flavonoids isolated from the leaves of Rhamnusalaternus L. (Rhamnaceae): A structure- activity relationship study, Food Chemistry, 116, pp. 258-264, 2009.

[28] E. Fenig, J. Nordenberg, E. Beery, J. Sulkes, L. Wasserman, Combined effect of aloe-emodin and chemotherapeutic agents on the proliferation of an adherent variant cell line of Merkel cell carcinoma, Oncology Reports, 11, 213-217, 2004.

[29] G.E. Trease, and W.C. Evans, Pharmacognosy, 13th edition, English Language Book Society, Bailliere Tindall, Britain, London, 1989.

[30] O.N. Irobi, M. Young, and W.A. Anderson, Antimicrobial activity of Annato(Bixaorella) extract, Int J Pharmacog, 34, pp. 87-90, 1996.

[31] M. Waksmundzka-Hajnos, J. Sherma, and T. Kowalska. Thin Layer Chromatography in Phytochemistry, Chromatographic Science series, 99, pp. 820-821. CRC Press, Taylor \& Francis Group, 6000 Broken Sound Parkway NW, 2008. 